Colloquia Litteraria

UKSW

$2 / 2015$

MAGDALENA ZYCH-CHLUDZIŃSKA

\title{
RECEPCJA TWÓRCZOŚCI JÓZEFA WITTLINA PO 1989 ROKU
}

Odwilż po 1989 roku, kiedy po latach hibernacji na rynek wydawniczy powróciły dzieła zapomnianych emigrantów, nie zaowocowała niestety pełnym kontaktem tych twórców z czytelnikiem. Selektywne traktowanie listy publikowanych pisarzy i niedostatek zainteresowania krytycznego sprawiły, że twórczość wielu polskich artystów po dwudziestu pięciu latach wciąż nie znalazła swojego miejsca w ojczystym kanonie.

Jednym z nieopisanych wciąż pozostaje Józef Wittlin. Za życia pisarza powodem milczenia na jego temat były, oczywiście, polityka i cenzura, a także powolny proces twórczy artysty. Już w 1956 roku Wittlin wspominany był przez Antoniego Marczyńskiego w artykule Losy artystów polskich jako „niegdyś znakomity pisarz”, którego jedyną pracą literacką za oceanem było przetłumaczenie Hiroszimy Herseya. Jak napisał w 2001 roku Zbigniew Fronczek, komentując brak popularności twórczości Wittlina:

Można powiedzieć, że zostawił zbyt skromny dorobek. Bliższe prawdy będzie stwierdzenie, że jego oryginalnej twórczości poświęcono niewiele uwagi ${ }^{1}$.

Autor Soli ziemi był nieobecny w polskiej krytyce od momentu emigracji, został pominięty $w$ Dziejach literatury polskiej Krzyżanowskiego, wydanych w roku śmierci pisarza, a we wstępach do rzadkich

1 Zbigniew Włodzimierz Fronczek, Pamięć o homerydzie, „Nasz Dziennik”, 3-4.03.2001, nr 53. 
wznowień dzieł emigranta określano go jako twórcę współpracującego z wrogimi rozgłośniami i wydawnictwami. Dopiero śmierć Wittlina sprawiła, że został on przypomniany polskiej publiczności, lecz, jak zauważa Wojciech Wyskiel:

Po jego śmierci nie opublikowano już takiej książki-pomnika jak Pamięci Jana Lechonia, Przebity światłem czy Książka o Grydzewskim. Niewielu zostało takich, co respektują te obyczaje, niewielu też, którzy mogliby wysłać wspomnienie ${ }^{2}$.

Również sam Wittlin pod koniec życia wspominał, że przeżył całą swoją literacką generację. To on, o czym świadczą jego eseje, stał na straży pamięci o wybitnych talentach swojej epoki. Po roku 1989 prace krytycznoliterackie o twórczości Wittlina ograniczają się w większości do okolicznościowych recenzji towarzyszących rocznicom i kolejnym wydaniom dzieł pisarza. Znacznie częściej pokazują się w tygodnikach i dziennikach niż czasopismach humanistycznych, co przekłada się na jakość recepcji jego pisarstwa. W 1991 roku Tomasz Żółciński, recenzując Pisma pośmiertne i inne eseje, nakreślił ówczesny stan recepcji twórczości Wittlina:

Józef Wittlin, mimo całej wybitności pisarskiego talentu, z tomów poezji, prozy i esejów znany jest stosunkowo wąskiemu gronu czytelników. To nic, że głośna w dwudziestoleciu międzywojennym była jego powieść Sól ziemi. To nic, że już na powojennej emigracji wydał jeden z najpiękniejszych w dziejach polskiej eseistyki tom Orfeusz w piekle XX wieku. Jak zwykle dopiero pośmiertnie, od końca lat siedemdziesiątych, zaczął być przywracany krajowemu czytelnikowi, ale tylko w skromnym wyborze wierszy, dwukrotnym wznowieniu powieści Sól ziemi oraz esejach Mój Lwów, skreślonych w 1946 roku. Ukazał się również w Katowicach tom studiów o twórczości tego pisarza pod redakcją Ireneusza Opackiego. Wszystko to jednak nie przybliżyło dostatecznie sylwetki pisarza współczesnemu krajowemu

\footnotetext{
2 Wojciech Wyskiel, Kręgi wygnania. Jan Lechoń na obczyźnie (Krąg pierwszy i drugi), Kraków 1988, s. 60, cyt. za: Iwona Krzemińska, W zimnym krystalicznym blasku, „Poezja” 1990, nr 7/9, s. 40.
} 
czytelnikowi, nie wyznaczyło należnego mu jakże ważnego miejsca we współczesnej literaturze ${ }^{3}$.

Niestety, mimo kolejnych wydań i wznowień dzieł nazwisko Wittlina pozostaje obce czytelnikom, a znajomością jego twórczości może pochwalić się wąskie grono filologów. W ciągu dwudziestu pięciu lat, od 1989 roku, napisano o nim jedynie około stu dwudziestu artykułów. Dla porównania, zarówno Gombrowicz, jak i Miłosz, obydwaj emigranci, zebrali ponad dziesięć razy więcej komentarzy, a działający w kraju Marek Nowakowski - który nie był ulubieńcem salonów - prawie cztery razy więcej.

W 1990 roku wydane zostały wspomniane wcześniej materiały pokonferencyjne pt. Studia o twórczości Józefa Wittlina pod redakcją Ireneusza Opackiego. Rok później Jan Zieliński zebrał i opublikował zbiór Pisma pośmiertne i inne eseje, którego oceny pojawiały się w czasopismach jeszcze dwa lata później. W 1995 roku dwiema recenzjami upamiętniona została publikacja przekładów opracowanych przez Zygmunta Kubiaka pt. Przyjaźnie poetyckie Józefa Wittlina. Rok 1996 był rokiem niepowtarzalnym, jeśli chodzi o bogactwo artykułów poświęconych autorowi Soli ziemi. Z okazji stulecia narodzin pisarza i dwudziestej rocznicy jego śmierci opublikowano prawie dwadzieścia artykułów o Wittlinie, wydano listy pisarza, przygotowano okolicznościową wystawę w warszawskim Muzeum Literatury, a Anna Frajlich zorganizowała w Nowym Jorku konferencję „Between Lvov, New York and Ulysses' Ithaca. Józef Wittlin - poet, esseyist, novelist”, która szerokim echem odbiła się po obydwu stronach oceanu i do dziś pozostaje największą spośród wszystkich konferencji poświęconych Wittlinowi. W 1997 roku wydano polskie tłumaczenie monografii Wittlina opracowanej w 1973 roku przez Zoyę Yurieff, badaczkę rosyjskiego pochodzenia. Rok później ukazał się wybór poezji Wittlina ze wstępem Wojciecha Ligęzy. W 2000 roku wznowiono wydanie Orfeusza w piekle XX wieku. Rok później, z okazji kolejnej okrągłej rocznicy - w ćwierćwiecze śmierci pisarza, opublikowano materiały

\footnotetext{
3 Tadeusz Żółciński, Pisarski kufer podróżny, „Dziennik Ilustrowany”, 17.09.1991, nr 26.
} 
ze wspomnianej wcześniej konferencji w Nowym Jorku. Jedenaście lat później, w 2012 roku, na Uniwersytecie Jagiellońskim odbyła się konferencja „Etapy Józefa Wittlina”. Zbiór referatów, opracowanych przez Wojciecha Ligęzę i Wojciecha Wocława i opublikowanych dwa lata później w książce o tym samym tytule, stanowi jedno z najobszerniejszych wydawnictw dotyczących twórczości Wittlina, a teksty tam zamieszczone należy uznać za jedne z najwnikliwszych. W 2014 roku ogłoszono drukiem korespondencję Wittlina z Tymonem Terleckim (Listy 1944-1976), opracowaną przez Ninę Taylor-Terlecką.

Systematycznie ukazują się również teksty źródłowe - głównie poszczególne listy z bogatej korespondencji Wittlina i jego notatki intymne. Warto tutaj przypomnieć artykuł Ryszarda Zajączkowskiego Wolne usta poety, który wskazał na nieopracowany do tej pory rękopis dzienników pisarza, znajdujący się w Muzeum Literatury w Warszawie. Nadzieją napawa również fakt, że oprócz nakreślania sylwetki autora Soli ziemi w rubrykach typu: „godni przypomnienia” czy „pisarze zapomniani”, od 2000 roku sporadycznie zaczynają pojawiać się poważne artykuły historycznoliterackie poświęcone jego twórczości.

Widać również ogromne starania popularyzatorskie poszczególnych krytyków, w większości zainspirowanych postawą Elizabeth Wittlin-Lipton, córki pisarza, która zajmuje się spuścizną literacką ojca, darowując jego rękopisy badaczom. Dwa ważniejsze - konspekt kolejnych tomów Soli ziemi przygotowany dla niemieckiego wydawcy przez Elizabeth Wittlin-Lipton oraz notatki Wittlina z podróży po Europie - wydano w 1992 i 1993 roku w czasopiśmie „Regiony”; reszta czeka jeszcze w archiwach na opracowanie i publikację. Elizabeth Wittlin-Lipton podtrzymuje również pamięć o ojcu, goszcząc niemal na wszystkich konferencjach naukowych poświęconych jego dziełom oraz regularnie udzielając wywiadów. Jak sama pisze:

Nie mogłyśmy po prostu z mamą nie oddać Cię w ręce charyzmatycznych, inteligentnych, enigmatycznych, uwodzicielskich, energicznych

\footnotetext{
4 Józef Wittlin, Der Roman des geduldigen Infanteristen, „Regiony” 1992, nr 3/4, s. 146-147; Józef Wittlin, W tych karteczkach... mój prawdziwy świat, „Regiony” 1993, nr 3, s. 132-139.
} 
i szczodrze kochających, choć czasem szokujących postkomunistycznych (mama tego nie dożyła) czytelników w Polsce, bo naprawdę tego chciałeś. I dopięłyśmy swego 5 .

Lista badaczy twórczości Wittlina nie wykracza co prawda znacznie poza nazwiska wspomnianych wyżej redaktorów nowych wydań jego dzieł i organizatorów konferencji poświęconych jego twórczości, jednakże ta wąska publiczność stale dba o pamięć o pisarzu, przywracając jego nazwisko na akademickie salony i powoli, dokładnie badając, interpretując i wyjaśniając trudną twórczość tego dziwnego klasyka. Do stałych badaczy twórczości Wittlina należał również wspomniany wcześniej Zygmunt Kubiak, którego artykuły poświęcone tłumaczeniom Odysei i Wittlinowskiemu zainteresowaniu kulturą śródziemnomorską są najdokładniejszymi analizami związków jego twórczości z Homerem. Nie można także zapomnieć o Jerzym Jarzębskim, Wojciechu Ligęzie, Wojciechu Wocławie, Pawle Kądzieli, Janie Zielińskim i Józefie Olejniczaku.

Wizerunek Wittlina, jaki wyłania się z ich badań i komentarzy, jest bardzo patetyczny i pomnikowy. Jak napisała Elizabeth Wittlin-Lipton:

Nie znosiłeś mitotwórstwa, a przecież nie z mojej winy [...], wymyślono Cię na nowo, stwarzając gargantuiczną postać judeochrześcijańskiego św. Franciszka ${ }^{6}$.

Pisarz jawi się jako tragiczny rycerz literatury, walczący o cnoty niegdyś pisane wielkimi litrami, jak Piękno, Prawda, Wiara, Honor, które sam uważa za skazane na wyginięcie; jako człowiek walczący o wartość każdego istnienia, a zwłaszcza ubogiego i niewinnego; jako pielgrzym do miejsc nieistniejących; strażnik upominający się o pamięć zwłaszcza dla tych wydarzeń i ludzi, o których wszyscy chcą zapomnieć; jako ostatni homeryda i wielki epik.

A przecież nie da się odnieść wizerunku wynikającego z artykułów krytycznych do powszechnej czytelniczej świadomości.

5 Elizabeth Wittlin-Lipton, Poeta i jego córka, „Tygiel Kultury” 1997, nr 1/2, s. 57.

6 Tamże, s. 53. 
W podręcznikowych kompendiach wiedzy o Wittlinie wciąż pokutują pewne utrwalone schematy myślowe, utarte określenia, które w podobnych konfiguracjach powtarzają się niezmiennie od wielu lat. Krytycznoliteracki stempel nadany Wittlinowi w latach 70. XX wieku jest wciąż odbijany w artykułach pisanych dzisiaj. Wciąż natrafiamy między innymi na cytat z Traktatu poetyckiego Czesława Miłosza o łyżce zupy wkładanej w „zarosłe usta człowieczego głodu” - przy okazji wspomnienia o nominacji do literackiej nagrody Nobla dla Wittlina w 1939 roku i o pochlebnej recenzji, którą Tomasz Mann wystawił Soli ziemi. Wittlin jest określany jako ekspresjonista, pacyfista; jego powieść - nazywana polską wersją Przygód dobrego wojaka Szwejka albo $\mathrm{Na}$ zachodzie bez zmian, Hymny - krzykiem wywołanym doświadczeniem wojny, a zbiory esejów - jednymi z najpiękniejszych w dziejach polskiej literatury. Samego pisarza kreuje się na postać tragiczną, wygnańca, perfekcjonistę i idealistę.

Istnieje również tendencja do synchronicznego ujmowania tematów i obrazów, które co prawda obsesyjnie nawracają w twórczości Wittlina, ale występują w ramach różnych gatunków literackich i na przestrzeni kilkudziesięciu lat. Do tematów fascynujących pisarza krytycy zaliczają trzy główne motywy. Pierwszym jest śmierć - jako ostateczność, stały horyzont twórczości Wittlina i perspektywa nadająca jego myśleniu szczególny rys. Drugim - Bóg, ale nie religia, chrześcijaństwo czy Kościół jako struktura, lecz bardziej duchowość z judaistycznymi korzeniami, bliska Gandhiemu i świętemu Franciszkowi. Trzecim - transcendencja jako cel sztuki i próba przezwyciężenia śmierci. Ewolucja tych motywów w twórczości Wittlina wciąż czeka na opracowanie. Brakuje również dokładnego zbadania, jakie miejsce zajmuje twórczość tego pisarza wobec twórczości innych ludzi pióra: Rilkego ${ }^{7}$, Conrada, Rotha, Eliota ${ }^{8}$,

\footnotetext{
7 Por. Katarzyna Szewczyk-Haake, Co się z nami stanie albo o co mógłby Józef Wittlin zapytać Rainera M. Rilkego, „Teksty Drugie” 2012, nr 1/2.

${ }^{8}$ Por. Zygmunt Kubiak, Co uczynili dla nas? O Józefie Wittlinie i literaturze emigracyjnej, „Więź” 1996, nr 11/12.
} 
Miłosza ${ }^{9}$, Brandstaettera $^{10}$, żeby wymienić choćby kilka nazwisk wskazanych przez krytykę. Jedynie w pobieżnych szkicach określono także postawę twórcy wobec polskiej tradycji literackiej, zwłaszcza romantyzmu ${ }^{11}$ i Młodej Polski ${ }^{12}$. Omówienie obu tych problemów czeka na rozwinięcie.

I gdzieś pomiędzy tymi dwoma obrazami, prezentowanymi przez krytyków i jednorazowych recenzentów, jawi się Wittlin widziany oczami przyjaciół i gości jego domu w Nowym Jorku. Jest to drobnej postury hipochondryk z czarnym poczuciem humoru, o mieszczańskich manierach, ogromnej erudycji i elegancji. Europejczyk zagubiony w Nowym Jorku, którego „klasycyzm i katolicyzm są [...] nie systemem, tylko aurą duszy, szczęściem życia"13.

Fakt, że twórczość Wittlina jest obca współczesnemu czytelnikowi, nie wynika jedynie $\mathrm{z}$ jej słabej obecności na rynku wydawniczym. Jest w niej coś obcego, anachronicznego, co powoduje, że interpretacja tej literatury sprawia trudności nawet filologom. Jest w niej pewna bezkompromisowość, duma, przebija z niej postawa poety odpowiedzialnego za każde wypowiedziane słowo, wiecznie opowiadającego się po stronie Prawdy i pochylającego się nad losem każdego człowieka. Jak napisał Jarosław Klejnocki:

Jest w tej prozie coś niedzisiejszego, co czyni ja niezwykłą, ale i nieznośną. Autentyczność. Wygląda czasem na zbytnią zacność, może nawet naiwność, jedno jest pewne - dzisiaj się tak nie pisze. [...]

\footnotetext{
9 Por. Katarzyna Szewczyk-Haake, Ekspresjonizm jako «dobro wspólne». O pierwiastkach ekspresjonistycznych we wczesnej twórczości Czesława Miłosza, „Ruch Literacki” 2012, nr 4-5.

10 Por. Ryszard Zajączkowski, Spotkanie z oddalenia i na piśmie. O niektórych wątkach z listów między Józefem Wittlinem i Romanem Brandstaetterem, w: Etapy Józefa Wittlina, red. Wojciech Ligęza, Wojciech S. Wocław, Kraków 2014.

11 Por. Romuald Cudak, "Otom przed Tobą, Abraham». Lektura wiersza Józefa Wittlina «Trwoga przed śmiercią», w: Studia o twórczości Józefa Wittlina, pod red. Ireneusza Opackiego, Katowice 1990.

12 Por. Zygmunt Kubiak, Stulecie wielkiego epika, „Tygodnik Powszechny” 1996, nr 33 .

13 Jan Lechoń, Dziennik 3 (1 stycznia 1953 - 30 maja 1956), Warszawa 1993, s. 450.
} 
Czytając Wittlina, mam nieodparte wrażenie obcowania $\mathrm{z}$ duchem tych czasów, gdy „nie” znaczyło bardziej „nie”, a „tak” znaczyło bardziej „tak”"14.

Ta cecha charakteru pisarza (autentyczność) przekłada się na wszystkie elementy twórczości. Pisząc o stylu artysty, wspomina o tym Maciej Krassowski:

To, co najbardziej uderza w poezji Wittlina, jest swoista bezpretensjonalność jego języka. Zupełnie jakby nie chciał się zbytnio przypodobać współczesnym i potomnym, jakby dbał jedynie o duchowo-intelektualny kształt swojego dzieła ${ }^{15}$.

Wartości, o których mowa wyżej, już w czasach współczesnych Wittlinowi były zbyt anachroniczne, a przestrzeganie zasad wynikających z cenienia tych wartości uchodziło za nazbyt wymagające. Potrzebna jest bardzo uważna lektura, żeby nie dać się przytłoczyć szeregowi wymagań moralnych, jakie stawia przed czytelnikiem autor. Nie można traktować ich jako reliktów dawnych czasów i brać ich w cudzysłów, nie przykładając do współczesności. Pisząc o Wittlinie, łatwo jest wpaść w pułapkę patosu i zbyt dużego dystansu - a uleganie obydwu tym skrajnościom skutkuje uproszczeniami.

Jeszcze jedną sprawę warto podkreślić. Po 1989 roku na łamach czasopism nie zaistniał żaden spór wokół twórczości Wittlina. Wszystkie recenzje są ocenami pochlebnymi, uznającymi Wittlina za niesłusznie zapomnianego klasyka literatury, jak choćby wypowiedź Małgorzaty Baranowskiej:

Sól ziemi jest być może najlepszą powieścią XX wieku i jedną z najdokładniej zapomnianych ${ }^{16}$.

\footnotetext{
14 Jarosław Klejnocki, Czytając Józefa Wittlina (na marginesie «Pism pośmiertnych» i innych esejów), „Topos” 1997, nr 4, s. 29.

15 Maciej Krassowski, Odyseusz w labiryncie XX wieku, „Wiadomości Kulturalne” 1996, nr 38, s. 4 .

16 Małgorzata Baranowska, Odyseusz nie wrócił, „Gazeta Wyborcza”, 3.o8.2001, nr 180 .
} 
Czy dwie następne, które powtarzają podobne oceny:

Nie wiem, czy Wittlin jest najwybitniejszym powieściopisarzem, czy też celował w homeryckich przekładach, albo może najświetniej wypada w swej eseistyce ${ }^{17}$.

Wittlin jest pisarzem bardzo ważnym i jednym z mistrzów polskiego eseju $^{18}$.

Te recenzje mają jeszcze jeden wspólny element - zupełnie pomijają twórczość poetycką Wittlina. Istnieje powszechna opinia, według której wiersze tego pisarza, a zwłaszcza Hymny (ponieważ twórczości emigracyjnej poświęcono bardzo niewiele uwagi), są twórczością drugiej kategorii w stosunku do jego utworów prozatorskich. Marian Kisiel poświęcił wstęp swojego artykułu temu zagadnieniu, pisząc:

Stała się oto, jak sądzę, rzecz niebywała. Wittlina nie da się wykreślić z kart literatury tworzonej między wojnami (wszak jest autorem Soli ziemi, książki ważnej i w jakimś stopniu modelowej dla polskiego ekspresjonizmu), a jednocześnie próbuje się go „okraść”, próbuje się wmówić, że jest to przede wszystkim pisarz. I jeszcze, powiedzmy, translator, eseista ${ }^{19}$.

Badacz pokazuje, jak na recepcji tej konkretnej twórczości (Wittlina) wciąż zaważają słowa napisane przez Juliana Przybosia w Chamułach poezji (1926) i jak niewiele trudu zadają sobie krytycy, by mieć na jej temat własne zdanie, przekraczające utarte schematy. Hymny Wittlina traktuje się jako dzieło mniej wartościowe, które nie oparło się upływowi czasu. Uważa się je za produkt ekspresjonizmu zbyt mocno nawiązujący do Kasprowicza, korzystający ze zużytej poetyki romantycznego patriotyzmu, po raz kolejny i odtwórczy eksploatujący conradowski bunt. Istnieją również artykuły stojące w opozycji do

\footnotetext{
17 Zbigniew Florczak, Legendarny Wittlin, „Nowe Książki” 1992, nr 2/3.

18 [lektok], Wśród książek [rec. Józef Wittlin, Pisma pośmiertne i inne eseje], „Tygodnik Powszechny", 18.08.1991, nr 33.

19 Marian Kisiel, Poezja Świadectwa. O «Hymnach» Józefa Wittlina, w: Studia o twórczości Józefa Wittlina, dz.cyt., s. 8-9.
} 
tych przekonań, jak np. Postscriptum do zwątpienia? autorstwa Marii Surówki („Więź” 2010, nr 7) czy Bliźni w świecie poetyckim Józefa Wittlina. Wokół zagadnień metafizycznych i moralnych, napisany przez Joannę Kosturek (Etapy Józefa Wittlina, dz.cyt., s. 99-114). Są to solidne prace interpretacyjne, które udowadniają, że, jak napisał Sergiusz Sterna-Wachowiak, zanim postawi się twórczość poetycką Wittlina w piekle albo niebie literatury, trzeba zacząć od dokładnej lektury ${ }^{20}$.

Szukając przyczyny zapomnienia i nieobecności Wittlina we współczesnej świadomości czytelniczej, a także przyczyn trudności przywrócenia go do literackiej dyskusji - mimo starań wielu popularyzatorów - trzeba stwierdzić, że jego twórczość nigdy nie będzie modna. Jego dzieła nie trafiły na swój moment w historii. Wydaje się wręcz, że czasy, w których zyskałby szerokie uznanie, minęły dawno przed narodzinami pisarza. Zarazem jednak dzięki autentyczności Wittlina i randze poruszanych przez niego tematów istnieje ogromne prawdopodobieństwo, że jego twórczość nigdy nie przeminie i nie straci na swojej aktualności, tak jak to się dzieje z niejednym przedmiotem chwilowych fascynacji krytyków. Marian Kisiel trochę enigmatycznie napisał o Wittlinie jako o pisarzu „ważnym przez swą drugorzędność” ${ }^{21}$. Wydaje mi się, że chodziło mu właśnie o ten rodzaj wiecznego trwania, niezależnego od aktualnych tendencji literackich.

Czas już zdążył zweryfikować twórczość Józefa Wittlina, a poglądy krytyków i badaczy na jej temat się utarły. Debiutanckie Hymny są pomijane („nie wytrzymały próby czasu”). Eseje - nieznane arcydzieło od 1991 roku nadal są nieodrobioną lekcją krytyków. Tłumaczenia Odysei, zwłaszcza drugie i trzecie, wciąż uważa się za niedościgniony wzór. A największe dzieło autora, Sól ziemi, stała się niesłusznie zapomnianą wielką powieścią, której brak w obiegu historycznoliterackim dziwi tym bardziej, że jej wydanie sprowokowało głośne i entuzjastyczne komentarze oraz bardzo dobre recenzje nie tylko w kraju, ale

\footnotetext{
20 Sergiusz Sterna-Wachowiak, Poeta i łódeczka życia, „Nowe Książki” 1999, nr 5, s. 65 .

21 Marian Kisiel, dz.cyt., s. 9.
} 
i na Zachodzie. Ten stan rzeczy prowokuje do pytania, zadanego już przez Marcina Piaseckiego, czy Wittlin byłby tak samo zapomniany, gdyby udało mu się napisać planowaną kontynuację Soli ziemi - dwa kolejne tomy składające się na trylogię Powieść o cierpliwym piechurze.

\section{Summary \\ Reception of Józef Wittlin's works after 1989}

The article surveys the current state of research on Józef Wittlin's works. It examines and summarizes evidence of the reception of his writings after 1989. The name of the writer remains obscure to Polish readership, while opinions about his works do not go beyond trite phrases. Wittlin's debut work, Hymny, is overlooked by critics, his essays await edition, and Sól Ziemi - Wittlin's greatest achievement - unjustly became a forgotten novel.

Magdalena Zych-Chludzińska (Uniwersytet Kardynała Stefana Wyszyńskiego w Warszawie) - doktorantka na Wydziale Nauk Humanistycznych UKSW. 